\title{
Skeletal muscle fiber-type distribution and habitual physical activity in daily life.
}

Citation for published version (APA):

den Hoed, M., Hesselink, M. K., \& Westerterp, K. R. (2009). Skeletal muscle fiber-type distribution and habitual physical activity in daily life. Scandinavian Journal of Medicine \& Science in Sports, 19(3), 373380. https://doi.org/10.1111/j.1600-0838.2008.00782.x

Document status and date:

Published: 01/01/2009

DOI:

10.1111/j.1600-0838.2008.00782.x

Document Version:

Publisher's PDF, also known as Version of record

Document license:

Taverne

\section{Please check the document version of this publication:}

- A submitted manuscript is the version of the article upon submission and before peer-review. There can be important differences between the submitted version and the official published version of record.

People interested in the research are advised to contact the author for the final version of the publication, or visit the DOI to the publisher's website.

- The final author version and the galley proof are versions of the publication after peer review.

- The final published version features the final layout of the paper including the volume, issue and page numbers.

Link to publication

\footnotetext{
General rights rights.

- You may freely distribute the URL identifying the publication in the public portal. please follow below link for the End User Agreement:

www.umlib.nl/taverne-license

Take down policy

If you believe that this document breaches copyright please contact us at:

repository@maastrichtuniversity.nl

providing details and we will investigate your claim.
}

Copyright and moral rights for the publications made accessible in the public portal are retained by the authors and/or other copyright owners and it is a condition of accessing publications that users recognise and abide by the legal requirements associated with these

- Users may download and print one copy of any publication from the public portal for the purpose of private study or research.

- You may not further distribute the material or use it for any profit-making activity or commercial gain

If the publication is distributed under the terms of Article $25 \mathrm{fa}$ of the Dutch Copyright Act, indicated by the "Taverne" license above, 


\title{
Skeletal muscle fiber-type distribution and habitual physical activity in daily life
}

\author{
M. den Hoed ${ }^{1}$, M. K. C. Hesselink ${ }^{2}$, K. R. Westerterp ${ }^{1}$ \\ ${ }^{1}$ Department of Human Biology, Maastricht University, Maastricht, The Netherlands, ${ }^{2}$ Department of Movement Sciences, \\ Maastricht University, Maastricht, The Netherlands \\ Corresponding author: Marcel den Hoed, Department of Human Biology, Maastricht University, P.O. Box 616, 6200MD \\ Maastricht, The Netherlands. Tel: +3143 3882115, Fax: +3143 3670976, E-mail: m.denhoed@hb.unimaas.nl
}

Accepted for publication 10 January 2008

The capacity to perform physical activity largely depends on physical fitness. Muscle fiber-type distribution (Muscle ${ }_{\text {FTD }}$ ) is associated with physical fitness and may influence the capacity to perform physical activity. The purpose of this study was to determine whether habitual physical activity in daily life $\left(\mathrm{PA}_{\mathrm{DL}}\right)$ and Muscle $_{\mathrm{FTD}}$ are related. Thirty-eight healthy non-athletes (31 women, 7 men) were recruited. $\mathbf{P A}_{D L}$ was measured twice for 14 days using a tri-axial accelerometer for movement registration (Tracmor). From Tracmor output, the proportion of time subjects were physically active at low, moderate, and high intensities was determined (\%Low, \%Moderate, and \%High, respec- tively). A total activity index $\left(\mathbf{P A}_{\text {index }}\right)$ and sub-scores on work, leisure-time and sports were obtained using the Baecke questionnaire. Muscle FTD $_{\text {was determined using }}$ immuno-fluorescence against respective myosin heavy chain isoforms. No relationship was observed between $\mathbf{P A}_{\mathrm{DL}}$ and Muscle $_{\text {FTD }}$ \%Low, \%Moderate, and \%High, as well as $\mathbf{P A}_{\text {index }}$ and its sub-scores, were not related to Muscle FTD $_{\text {TI }}$ either. The time spent on sports was associated with the proportion of type $\mathrm{I}$ and $\mathrm{II}_{\mathrm{X}}$ fibers $(P=0.06$ and $P<0.01$, respectively). In conclusion, Muscle FTD $_{\text {probably cannot }}$ explain why some people are more prone to engaging in physical activities than others.
Activity-related energy expenditure is the most variable component of total energy expenditure (Ravussin \& Swinburn, 1992) and appears to be an important determinant of energy balance (Schoeller et al., 1997). This implies that a reduced physical activity is a potentially important contributor to a predisposition to obesity (Heitmann et al., 1997; Weinsier et al., 1998; Esparza et al., 2000; Wardle et al., 2001; Ekelund et al., 2002). In a recent twin study, habitual physical activity in daily life $\left(\mathrm{PA}_{\mathrm{DL}}\right)$ was determined using a tri-axial accelerometer for movement registration. Based on the difference in intra-pair correlation in $\mathrm{PA}_{\mathrm{DL}}$ between monozygotic and dizygotic twins ( $R=0.88$ and 0.42 , respectively), additive genetic factors were concluded to explain $78 \%$ of intersubject variation in $\mathrm{PA}_{\mathrm{DL}}$ (Joosen et al., 2005). This suggests that genes determine to a large extent whether a person is prone to engaging in physical activities. How $\mathrm{PA}_{\mathrm{DL}}$ is affected by the genotype remains to be established.

One of the potential factors through which the genetic background could affect $\mathrm{PA}_{\mathrm{DL}}$ is skeletal muscle fiber-type distribution (Muscle FTD $_{\text {) }}$ (Komi et al., 1977; Gollnick \& Matoba, 1984; Simoneau et al., 1985; Lortie et al., 1986; Simoneau \& Bou- chard, 1995), defined as the relative number of type I, $\mathrm{II}_{\mathrm{A}}$, and $\mathrm{II}_{\mathrm{X}}$ muscle fibers (\% Type $\mathrm{I}, \%$ Type $\mathrm{II}_{\mathrm{A}}$, and $\%$ Type $\mathrm{II}_{\mathrm{X}}$, respectively). Based on monozygotic and dizygotic twin studies, it has been estimated that approximately $45 \%$ of the variation in \% Type I is associated with inherited factors (Simoneau \& Bouchard, 1995). Muscle $_{\mathrm{FTD}}$ is strongly associated with physical fitness, usually measured by maximal oxygen uptake $\left(\mathrm{VO}_{2 \max }\right)$, and might thereby influence the capacity to perform physical activity (Hedman et al., 2002). Indeed, positive associations between leisure-time physical activity $\left(\mathrm{PA}_{\text {leisure }}\right)$, measured using questionnaires and interviews, and \% Type I have been observed (Tikkanen et al., 1998; Hedman et al., 2002; Karjalainen et al., 2006). Considering the aforementioned, it might well be that part of the genetic contribution to $\mathrm{PA}_{\mathrm{DL}}$ results from Muscle $_{\text {FTD }}$. Therefore, the aim of this study was to examine the association between habitual $\mathrm{PA}_{\mathrm{DL}}$ and Muscle $_{\mathrm{FTD}}$ in a population of healthy, young adults. $\mathrm{PA}_{\mathrm{DL}}$ was hypothesized to be higher in subjects with a Muscle FTD $_{\text {associated previously }}$ with a higher physical fitness, i.e. a higher \% Type I and a lower \%Type $\mathrm{II}_{\mathrm{X}}$ (Gollnick \& Matoba, 1984). 


\section{den Hoed et al.}

Table 1. Subject characteristics

\begin{tabular}{lcc}
\hline & Men & Women \\
\hline$n$ & 7 & 31 \\
Age (years) & $20 \pm 2$ & $20 \pm 2$ \\
BM (kg) & $79.3 \pm 14.1$ & $63.1 \pm 8.2^{\dagger}$ \\
Height (m) & $1.84 \pm 0.06$ & $1.69 \pm 0.06^{\dagger}$ \\
BMl (kg/m $\left.{ }^{2}\right)$ & $23.2 \pm 3.0$ & $22.0 \pm 2.5$ \\
\hline
\end{tabular}

$\mathrm{BM}$, body mass; BMI, body mass index; values are means $\pm \mathrm{SD}$. Significant gender difference: ${ }^{\dagger} P<0.001$.

\section{Materials and methods}

\section{Subjects}

Based on an effect size of 0.25 , a power calculation indicated that 33 subjects are required for a power of 0.8 in simple linear regression analyses. Taking a dropout rate of $15 \%$ into account, 38 healthy, non-smoking subjects (31 females, 7 males) aged $20 \pm 2$ years were recruited to participate in this study. Subjects were not using any medication except for oral contraceptives. Recruitment was carried out using flyers in the university building. Subjects spending over $2 \mathrm{~h} /$ week on endurance sports, or $5 \mathrm{~h}$ on sports in general, were excluded from participation to minimize the effect of exercise training on Muscle $_{\text {FTD }}$. The subjects who were recruited either did not participate in sports or met the aforementioned criterion. These subjects participated in sports on a recreational basis and in a wide range of sports. Information about the purpose and protocol of the study, as well as its risks and discomfort were provided both orally and in writing. All subjects provided written informed consent before participating in the study. The study conformed to the standards set by the Declaration of Helsinki, and the local Ethics Committee approved the study. Subject characteristics $(n=38)$ are presented in Table 1.

\section{$P A_{D L}$}

$\mathrm{PA}_{\mathrm{DL}}$ was measured using a tri-axial accelerometer for movement registration (Tracmor IV; Philips Research, Eindhoven, the Netherlands) sensitive to a wide range of body movements. The accelerometer has been validated against doubly labeled water, the gold standard for measuring energy expenditure in daily life (Plasqui et al., 2005). The Tracmor registers accelerations of the trunk along the antero-posterior, medio-lateral, and longitudinal axes using three uni-axial piezo-electric accelerometers (details are provided elsewhere; Plasqui et al., 2005). To ensure a valid reflection of long-term daily life activities, the accelerometer was worn for two 14-day periods under free-living conditions. Subsequently, $\mathrm{PA}_{\mathrm{DL}}$ was acquired by summing the output of all three axes and is represented as Megacounts per day (Mcnts/day). $\mathrm{PA}_{\mathrm{DL}}$ was defined as the average of both measurement periods.

Subjects were instructed to wear the Tracmor from the moment they woke up in the morning until they went back to bed at night. To verify whether subjects lived up to this instruction, waking hours and clock times of wearing the Tracmor were noted. To make sure only representative days were included, the difference between the total time the subject was awake and the time the accelerometer was worn was not allowed to exceed $75 \mathrm{~min} /$ day. The few days during which this difference was more than $75 \mathrm{~min}$ were excluded from the analysis. This resulted in an average of 26 representative days per subject. To make sure the subjects met the inclusion criterion concerning their participation in sports, the actual sporting hours were also recorded in the diary.

Using Tracmor data, the proportion of time subjects were physically active at a low, moderate, and high-intensity (\%Low, \%Moderate, and \%High, respectively) was determined. The cut-off points for the intensity categories were determined in a pilot study $(n=5)$. The cut-off point for low-intensity physical activity was set by Tracmor outputs associated with walking on a treadmill at $3.5 \mathrm{~km} / \mathrm{h}$, which corresponds with approximately 3 metabolic equivalents (METs). For moderate-intensity physical activity, a Tracmor output associated with walking on a treadmill at $5 \mathrm{~km} / \mathrm{h}$ was used, which corresponds with approximately 4.5 METs (Ainsworth et al., 2000). The relevant Tracmor outputs were $16.0 \pm 3.0 \mathrm{Mcnts} / \mathrm{min}$ and $28.9 \pm 3.0 \mathrm{Mcnts} / \mathrm{min}$, respectively. The proportion of time per intensity category was calculated as the sum of all minutes per intensity category divided by the total duration of the measurement, i.e. 28 days minus the number of excluded days.

Using linear regression analysis in a population similar to the present study with respect to $\mathrm{PA}_{\mathrm{DL}}$, body composition and age, Plasqui et al. (2005) were able to predict physical activity level (PAL) with an explained variation of $70 \%$ using only $\mathrm{PA}_{\mathrm{DL}}$. This regression equation was used in the present study to estimate PAL.

Measures for physical activity during work, sports and leisure-time were obtained using the Baecke questionnaire (Baecke et al., 1982). Summing the scores of each section provided a total activity index $\left(\mathrm{PA}_{\text {index }}\right)$. Like the Tracmor, the Baecke questionnaire has been validated against doubly labeled water, with the $\mathrm{PA}_{\text {index }}$ explaining $45 \%$ of the variation in PAL (Philippaerts et al., 1999).

\section{Muscle sample analysis}

A muscle biopsy was obtained from the M. Vastus Lateralis under local anesthesia (xylocaine 2\%) using a Bergström needle with suction (Bergstrom, 1975). The Vastus Lateralis was selected because of the absence of large vessels or nerves in the region, the presence of type $\mathrm{I}_{1} \mathrm{II}_{\mathrm{A}}$, and $\mathrm{II}_{\mathrm{X}}$ muscle fibers in an ample amount (Staron et al., 2000) and the large inter-

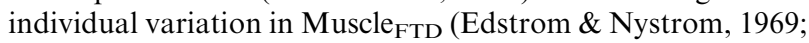
Staron et al., 1994). Biopsies were frozen in melting isopentane and stored in a pre-cooled aluminum cryo-vial at $-80^{\circ} \mathrm{C}$ until analyzed.

Serial transverse cryosections were cut $(5 \mu \mathrm{m})$ in a crysostat microtome (Leica; CM 3050, Rijswijk, the Netherlands) and thaw-mounted on uncoated pre-cleaned glass slides. After airdrying for $\sim 120 \mathrm{~min}$, sections were again stored at $-80{ }^{\circ} \mathrm{C}$ until processing for routine immunofluorescent staining against distinct myosin heavy-chain (MHC) isoforms.

Muscle fibers were characterized as type $\mathrm{I}_{,} \mathrm{II}_{\mathrm{A}}$, or $\mathrm{II}_{\mathrm{X}}$ using antibodies against the respective $\mathrm{MHC}$ isoforms. Briefly, airdried cryosections were treated for $5 \mathrm{~min}$ with $0.5 \%$ triton X-100 in phosphate-buffered saline (PBS), and washed for 5 min with PBS. Thereafter, a $0.05 \%$ Tween $20 /$ PBS dilution containing the primary antibody for MHCI diluted 1:50 (A4.840; DSHB, Iowa city, Iowa, USA), MHCII $_{\mathrm{A}}$ diluted 1:50 (N2.261, DSHB) and anti-laminin diluted 1:200 (L-9393; Sigma, Zwijndrecht, the Netherlands) was applied for $45 \mathrm{~min}$. After three 5-min washes with PBS the appropriate secondary antibodies [Alexa Fluor 555 Goat anti-Mouse $\operatorname{IgM}$ diluted 1:500 (A-21426), Alexa Fluor 488 Goat anti-Mouse IgG1 diluted 1:200 (A-21121), and Alexa Fluor 350 Goat antiRabbit IgG diluted 1:130 (A-11069) (Molecular Probes Invitrogen, Breda, the Netherlands)] were applied for $45 \mathrm{~min}$ at room temperature. Again, sections were washed with PBS 
three times for 5 min and embedded in Mowiol 4-88 (475904, Calbiochem, Amsterdam, the Netherlands).

After $24 \mathrm{~h}$, the slides were examined using a Nikon E800 Fluorescence microscope (Uvikon, Bunnik, the Netherlands). Images were captured using a color CCD camera (Basler $113 \mathrm{C}$, Basler vision technologies, Ahrensburg, Germany) with $\mathrm{MHCI}$ in red, $\mathrm{MHCII}_{\mathrm{A}}$ in green and laminin, a basement membrane marker to identify the myofiber boundary, in blue. All fibers without intracellular staining were considered to be type $\mathrm{II}_{\mathrm{X}}$ muscle fibers.

Digitally captured images $(\times 20$ magnification) were processed and analyzed using Lucia 4.8 software (Nikon; Düsseldorf, Germany). Muscle fiber typology was measured semiautomatically using a custom-written macro that identifies individual muscle fibers. Upon thresholding, red (MHCI), green $\left(\mathrm{MHCII}_{\mathrm{A}}\right)$, and unstained fibers $\left(\mathrm{MHCII}_{\mathrm{X}}\right)$ were identified and expressed as percentage of the total number of fibers identified. On average, Muscle $_{\mathrm{FTD}}$ was determined in $290 \pm 135$ fibers/subject.

\section{Maximal oxygen uptake}

$\mathrm{VO}_{2 \max }$ was determined during an incremental maximal intensity test on a calibrated electromechanically braked cycle ergometer (Lode Excalibur; Lode, Groningen, the Netherlands). The initial workload was set at $100 \mathrm{~W}$ for men and $75 \mathrm{~W}$ for women. Subjects were instructed to maintain their crank rate between 80 and 100 r.p.m. at all times during the test. After 5 min of warming up, workload increased with $50 \mathrm{~W}$ every $2.5 \mathrm{~min}$ until exhaustion. Exhaustion was defined as a sudden decline in crank rate below 60 r.p.m., usually resulting in the subjects giving up. Throughout the test, gas exchange was measured continuously using an Oxycon $\beta$ (Oxycon; Mijnhardt, Bunnik, the Netherlands). The analyzer was calibrated daily using a 3-L calibrated syringe (Sensormedics, Anaheim, CA, USA) and a gas mixture of known concentration $\left(5.0 \% \mathrm{CO}_{2}, 95.0 \% \mathrm{~N}_{2}\right) . \mathrm{VO}_{2 \max }$ was determined using a third-order polynome fitted through the data. The maximum of this polynome was considered the $\mathrm{VO}_{2 \max }$.

\section{Body composition}

Fat-free mass (FFM) and fat mass (FM) were determined as subject comparative measures for body composition. Therefore, anthropometric measurements were carried out in the morning after an overnight fast. Body mass was measured on an electric scale (ID 1 Plus; Mettler Toledo, Giessen; Germany) to the nearest $0.01 \mathrm{~kg}$. Height was measured to the nearest $0.1 \mathrm{~cm}$ (Model 220; SECA, Hamburg, Germany). Body volume was determined using the underwater weighing technique while correcting for residual long volume using the helium dilution technique (Volugraph VG 2000; Mijnhardt). Total body water was determined overnight using the deuterium dilution technique according to the Maastricht protocol (Westerterp et al., 1995). Body composition was subsequently calculated from body volume and total body water using Siri's three-compartment model (Siri, 1993).

\section{Statistics}

Differences between men and women were tested using Student's $t$-tests for unpaired samples. Differences in $\mathrm{PA}_{\mathrm{DL}}$ between the two measurement periods were evaluated using a Student's $t$-test for paired samples. Bivariate correlation was used to test the association between parameters of physical

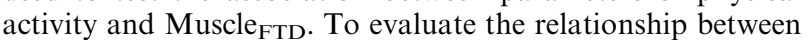
$\%$ Low, \%Moderate, \%High, and the time spent on sports

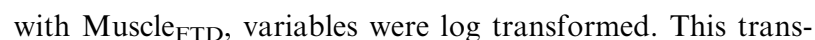
formation was applied to obtain a normal distribution of the residuals with homoskedasticity, i.e., an equal variance over the entire range of predicted values. Statistical analysis was carried out using the Statistical Package for Social Sciences (SPSS) version 11 for Macintosh OSX (SPSS Inc., Chicago, Illinois, USA). Data are expressed as means \pm SD. For associations, unstandardized coefficients and $95 \%$ confidence intervals, as well as $P$-values are provided. $P$-values $<0.05$ were considered statistically significant.

\section{Results}

$\mathrm{PA}_{\mathrm{DL}}$ was not significantly different between the two 14-day measurement periods $(P=0.14)$. Results on $\mathrm{PA}_{\mathrm{DL}}$ averaged over both periods, as well as on the proportion of time spent in each intensity category are presented in Table 2. $\mathrm{PA}_{\text {index }}$ and Baecke subscores, as well as the weekly time spent on sports, Muscle $_{\mathrm{FTD}}, \mathrm{VO}_{2 \max }$ and body composition are also shown in Table 2.

$\mathrm{PA}_{\mathrm{DL}}$ was comparable for men and women: 4128 vs $3704 \mathrm{Mcnts} /$ day, respectively (Table 2 ). The proportion of time spent in each intensity category was comparable between genders as well, although

Table 2. Data on physical activity, muscle fiber type distribution, and body composition

\begin{tabular}{|c|c|c|}
\hline & Men & Women \\
\hline $\mathrm{PA}_{\mathrm{DL}}$ (Mcnts/day) & $4128 \pm 636$ & $3704 \pm 675$ \\
\hline PAL & $1.88 \pm 0.10$ & $1.80 \pm 0.11$ \\
\hline \%Low (/24 h) & $96.5 \pm 1.0$ & $97.3 \pm 1.0$ \\
\hline$\%$ Moderate (/24 h) & $2.3 \pm 0.5$ & $2.1 \pm 0.9$ \\
\hline$\%$ High (/24 h) & $1.2 \pm 0.8$ & $0.7 \pm 0.4^{\S}$ \\
\hline $\mathrm{PA}_{\text {index }}$ & $8.1 \pm 1.0$ & $8.6 \pm 0.9$ \\
\hline Baecke work & $2.0 \pm 0.3$ & $2.2 \pm 0.3$ \\
\hline Baecke sport & $3.2 \pm 0.7$ & $3.0 \pm 0.6$ \\
\hline Baecke leisure & $3.0 \pm 0.3$ & $3.4 \pm 0.4^{*}$ \\
\hline Sports (h/week) & $2.2 \pm 1.8$ & $2.1 \pm 1.7$ \\
\hline \%Type I & $56.6 \pm 12.9$ & $59.6 \pm 10.6$ \\
\hline$\%$ Type $\|_{A}$ & $39.4 \pm 11.6$ & $37.1 \pm 10.3$ \\
\hline$\%$ Type $\|_{x}$ & $3.9 \pm 3.9$ & $3.3 \pm 5.1$ \\
\hline $\mathrm{VO}_{2 \max }(\mathrm{L} / \mathrm{min})$ & $4.0 \pm 0.8$ & $2.7 \pm 0.4^{\dagger}$ \\
\hline $\mathrm{VO}_{2 \max }(\mathrm{mL} / \mathrm{min} / \mathrm{kg} \mathrm{BM})$ & $51.1 \pm 5.1$ & $42.8 \pm 4.7^{\dagger}$ \\
\hline $\mathrm{VO}_{2 \max }(\mathrm{mL} / \mathrm{min} / \mathrm{kg} \mathrm{FFM})$ & $60.8 \pm 4.8$ & $58.4 \pm 5.7$ \\
\hline FFM (kg) & $66.3 \pm 9.9$ & $46.0 \pm 4.6^{\dagger}$ \\
\hline $\mathrm{FM}(\mathrm{kg})$ & $13.0 \pm 6.3$ & $17.1 \pm 4.8$ \\
\hline
\end{tabular}

$P A_{D L}$, physical activity in daily life as measured using a tri-axial accelerometer during two periods of 2 weeks; Mcnts/day, Megacounts per day; PAL, physical activity level, i.e., the factor by which total energy expenditure exceeds resting energy expenditure; \%Low, \%Moderate, and \%High, proportion of time subjects were physically activity at a low, moderate, and high-intensity respectively; $\mathrm{PA}_{\text {index }}$, total activity index measured with the Baecke questionnaire; Baecke Work, Sport, and Leisure, scores on each section of the Baecke questionnaire; Sports, weekly time spent on sports in hours; FFM, fat-free mass; FM, fat mass; \%Type I, \%Type $\|_{\mathrm{A}}$, and \%Type $\mathrm{I}_{\mathrm{X}}$, proportion of type $\mathrm{I}, \mathrm{I}_{\mathrm{A}}$, and $\mathrm{I}_{\mathrm{X}}$ muscle fibers; $\mathrm{VO}_{2 \max }$, maximal oxygen uptake, either absolute, or relative to body mass or FFM; Data are means \pm SD.

Significant gender difference: ${ }^{\star} P<0.05 ;{ }^{\S} P<0.01 ;{ }^{\dagger} P<0.001$. 


\section{den Hoed et al.}

$\%$ High was significantly higher in men: $1.2 \%$ vs $0.7 \%$ in women $(P<0.01)$. Men and women combined were physically active at a low, moderate, and high-intensity for approximately $97 \%, 2 \%$, and $1 \%$ of the time, respectively. This corresponds with 30 and $11 \mathrm{~min}$ of moderate and high-intensity physical activity per day. Application of the regression equation developed by Plasqui et al. (2005) to the present population showed that the PAL ranged from 1.62 to 2.04. Muscle $_{\text {FTD }}$ was not significantly different be-
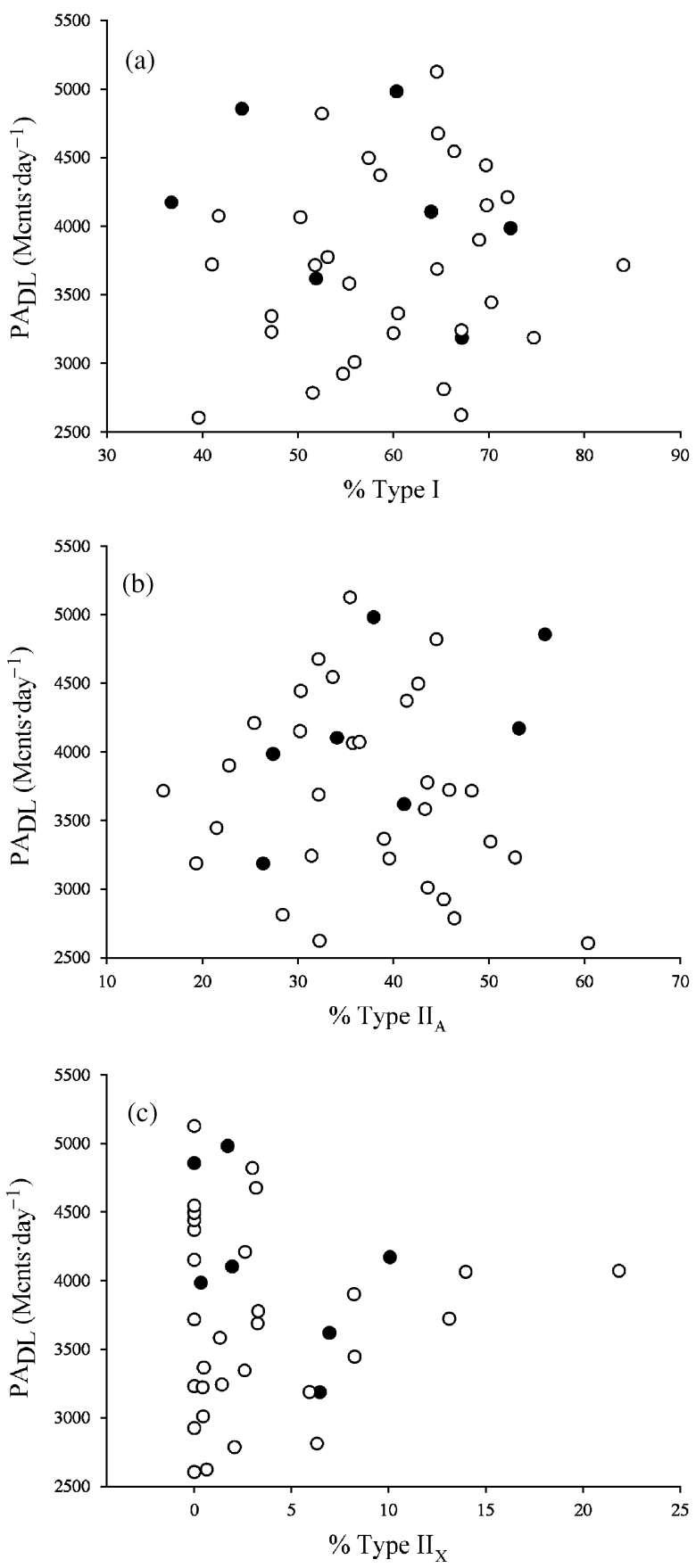

tween genders, which confirms the findings of previous studies (Bell et al., 1980; Kriketos et al., 1997; Evertsen et al., 1999; Staron et al., 2000; Jaworowski et al., 2002). When averaged for both genders, Muscle $_{\text {FTD }}$ was approximately 59\% type I, 38\% type $\mathrm{II}_{\mathrm{A}}$, and $3 \%$ type $\mathrm{II}_{\mathrm{X}}$.

No difference was found between men and women for the $\mathrm{PA}_{\text {index }}$ and Baecke sub-scores on work and sports (Table 2). Only the Baecke sub-score for physical activity during leisure-time was significantly
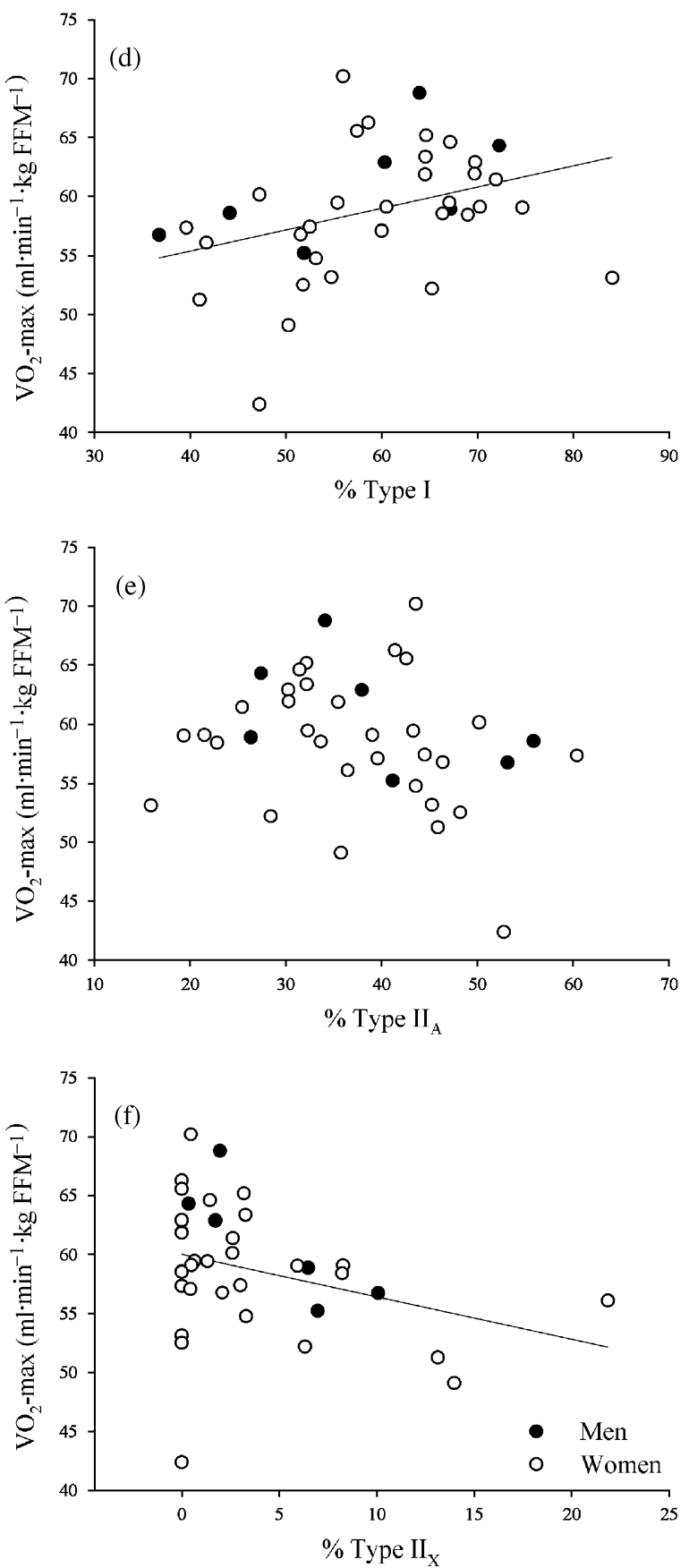

Fig. 1. Habitual physical activity in daily life and maximal oxygen uptake per kg fat-free mass as a function of muscle fibertype distribution. (a-c) Show habitual physical activity in daily life $\left(\mathrm{PA} \mathrm{DL}_{\mathrm{DL}}\right)$ as a function of the proportion of type $\mathrm{I}$, II $\mathrm{I}_{\mathrm{A}}$, and $\mathrm{II}_{\mathrm{X}}$ muscle fibers, respectively. (d-f) Show maximal oxygen uptake $\left(\mathrm{VO}_{2 \mathrm{max}}\right)$ expressed per $\mathrm{kg}$ fat-free mass (FFM) as a function of the proportion of type $\mathrm{I}_{1} \mathrm{II}_{\mathrm{A}}$, and $\mathrm{II}_{\mathrm{X}}$ muscle fibers, respectively.(d) $P<0.05$; (f) $P=0.05$. 
different between genders: $3.0 \pm 0.3$ vs $3.4 \pm 0.4$ for men and women, respectively $(P<0.05)$. The weekly time spent on sports did not differ between genders (Table 2). On average, subjects reported spending approximately $2 \mathrm{~h} /$ week on sports, which corresponds with approximately $17 \mathrm{~min} /$ day.

FFM is the strongest independent predictor of $\mathrm{VO}_{2 \max }$, alone explaining $86 \%$ of its variation $(P<0.001)$. Although $\mathrm{VO}_{2 \max }$ was significantly higher in men than in women, this difference did not remain after adjusting $\mathrm{VO}_{2 \max }$ for FFM. Based
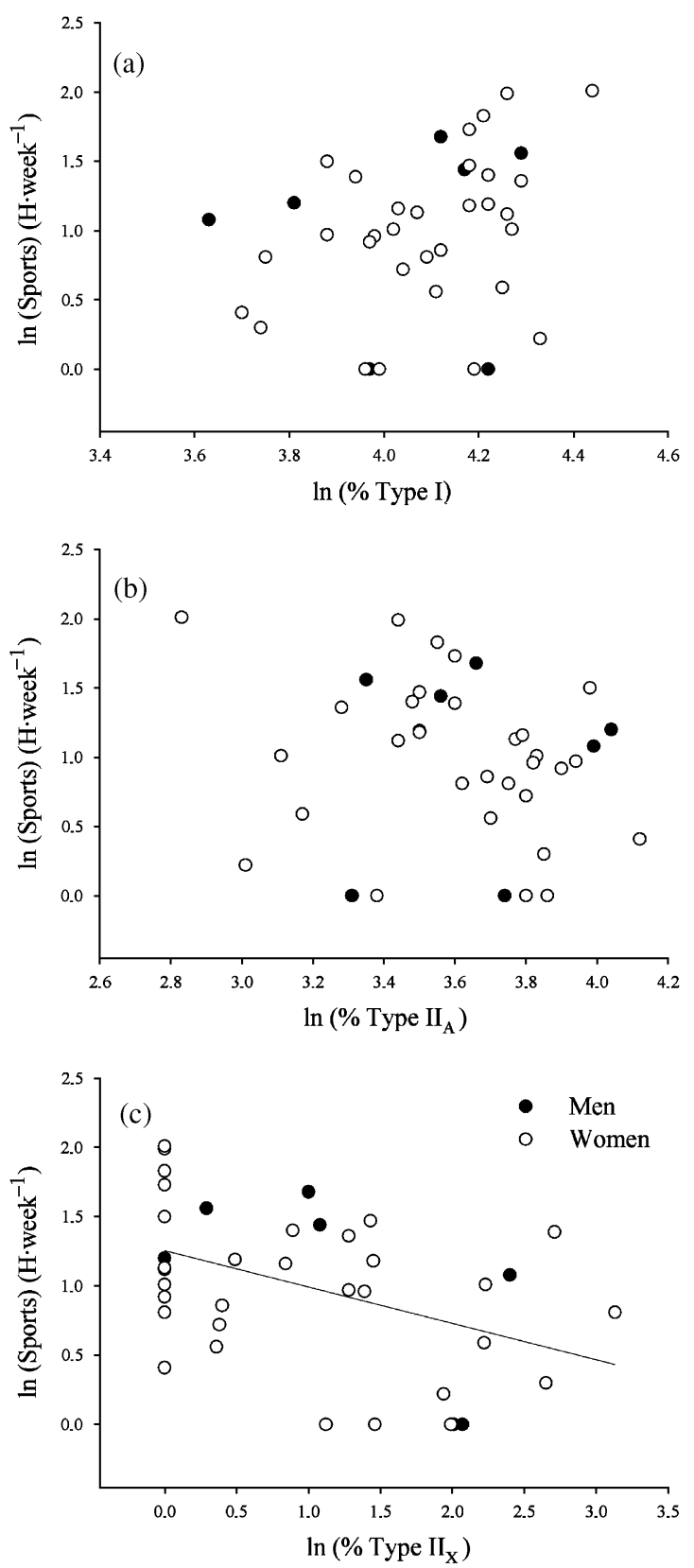

Fig. 2. Time spent on sports in $\mathrm{h} /$ week and the proportion of type $\mathrm{I}(\mathrm{a}), \mathrm{II}_{\mathrm{A}}(\mathrm{b})$, and $\mathrm{II}_{\mathrm{X}}$ (c) muscle fibers after natural $\log (\ln )$ transformation of both variables. (a) $P=0.06$;(c) $P<0.01$. on these results, both genders were combined for further analyses.

$\mathrm{VO}_{2 \max }$ expressed per kilogram FFM was positively associated with \% Type I $\left(R^{2}=0.13 ; P<0.05\right)$, and correlated borderline significantly with \% Type $\mathrm{II}_{\mathrm{X}}\left(R^{2}=0.10 ; P=0.05\right)$ (Fig. 1$)$. A trend towards a positive association was observed between $\mathrm{PA}_{\mathrm{DL}}$ and $\mathrm{VO}_{2 \max }$ adjusted for FFM $(P=0.09)$. $\mathrm{PA}_{\mathrm{DL}}$ on the other hand was not significantly associated with Muscle $_{\text {FTD }}(P$-values $>0.7)$ (Fig. 1). No associations were found between \%Low, \%Moderate, and $\%$ High with Muscle $_{\mathrm{FTD}}$ either $(P$-values $\geq 0.2)$. Moreover, neither the $\mathrm{PA}_{\text {index }}$ nor the Baecke subscores were significantly correlated with Muscle $_{\mathrm{FTD}}$ ( $P$-values $\geq 0.2)$. On the contrary, the time weekly spent on sports was negatively associated with \% Type $\mathrm{II}_{\mathrm{X}}\left(R^{2}=0.19 ; P<0.01\right)$ and tended to correlate positively with \% Type I $\left(R^{2}=0.09 ; P=0.06\right)$ (Fig. 2). All unstandardized regression coefficients, $95 \%$ confidence intervals and $P$-values are provided in Table 3.

\section{Discussion}

The capacity to perform physical activity was proposed previously to depend on physical fitness (Tikkanen et al., 1998; Hedman et al., 2002). Since Muscle $_{\text {FTD }}$ was shown to be strongly associated with physical fitness (Hedman et al., 2002), the former was considered to be a candidate to explain (part of) the inter-individual variation in $\mathrm{PA}_{\mathrm{DL}}$. The aim of this study was thus to determine whether habitual physical activity in daily life was associated with $\mathrm{Mu}-$ scle $_{\text {FTD }}$. To this end, PA $\mathrm{DL}_{\mathrm{DL}}$ was measured for two periods of 14 days using the Tracmor, a validated triaxial accelerometer for movement registration. The previously observed associations between physical activity and $\mathrm{VO}_{2 \max }$ and between $\mathrm{VO}_{2 \max }$ and $\mathrm{Mu}-$ scle $_{\text {FTD }}$ were confirmed in the present study. This affirms Muscle $_{\mathrm{FTD}}$ as a candidate to influence the capacity to perform physical activity.

To prevent an effect of physical exercise training on Muscle $_{\text {FTD }}$, subjects spending more than $2 \mathrm{~h} /$ week on endurance sports or more than $5 \mathrm{~h} /$ week on sports in general were excluded from participation. This resulted in an average engagement in sports of $2 \mathrm{~h} /$ week. Still, a wide range in $\mathrm{PA}_{\mathrm{DL}}$ was observed and the range in PAL observed indicates that sedentary as well as highly physically active subjects were recruited (Black et al., 1996; Westerterp, 2001).

No evidence was found for a relationship between $\mathrm{PA}_{\mathrm{DL}}$ and Muscle $_{\mathrm{FTD}}$. The accelerometer used in this study was also used by Joosen et al. (2005), who showed that the largest part of inter-subject variation in $\mathrm{PA}_{\mathrm{DL}}$ results from genetic variation. Hence, our results suggest that Muscle $_{\text {FTD }}$ probably 
Table 3. Unstandardized regression coefficients, $95 \%$ confidence intervals and $P$-values for all associations with muscle fiber type distribution

\begin{tabular}{|c|c|c|c|c|c|c|c|c|c|c|c|c|}
\hline \multirow[b]{3}{*}{$P A_{D I}$} & \multicolumn{4}{|l|}{ \%Type I } & \multicolumn{4}{|l|}{$\%$ Type $\|_{A}$} & \multicolumn{4}{|c|}{ \%Type $I_{X}$} \\
\hline & \multirow{2}{*}{$\begin{array}{l}B \\
2.7\end{array}$} & \multicolumn{2}{|c|}{$95 \% \mathrm{Cl}$} & \multirow{2}{*}{$\begin{array}{l}P \\
\text { NS }\end{array}$} & \multirow{2}{*}{$\begin{array}{c}B \\
-3.1\end{array}$} & \multicolumn{2}{|c|}{$95 \% \mathrm{Cl}$} & \multirow{2}{*}{$\begin{array}{l}P \\
\text { NS }\end{array}$} & \multirow{2}{*}{$\frac{B}{0.6}$} & \multicolumn{2}{|l|}{$95 \% \mathrm{Cl}$} & \multirow{2}{*}{$\begin{array}{l}P \\
\text { NS }\end{array}$} \\
\hline & & -18.3 & 23.6 & & & -25.1 & 19.0 & & & -46.7 & 48.0 & \\
\hline$\%$ Low $(24 / \mathrm{h})$ & -0.002 & -0.02 & 0.02 & NS & -0.003 & -0.02 & 0.01 & NS & 0.002 & -0.002 & 0.006 & NS \\
\hline$\%$ Moderate $(24 / \mathrm{h})$ & 0.06 & -0.5 & 0.7 & NS & 0.005 & -0.4 & 0.4 & NS & -0.04 & -0.2 & 0.08 & NS \\
\hline$\%$ High $(24 / h)$ & 0.1 & -1.1 & 1.3 & NS & 0.2 & -0.6 & 1.0 & NS & -0.1 & -0.4 & 0.09 & NS \\
\hline $\mathrm{PA}_{\text {index }}$ & 0.01 & -0.02 & 0.04 & NS & -0.01 & -0.04 & 0.02 & NS & -0.01 & -0.07 & 0.05 & NS \\
\hline Baecke work & -0.002 & -0.01 & 0.008 & NS & -0.0005 & -0.01 & 0.01 & NS & 0.01 & -0.01 & 0.03 & NS \\
\hline Baecke sport & 0.007 & -0.01 & 0.03 & NS & -0.001 & -0.02 & 0.02 & NS & -0.03 & -0.07 & 0.01 & NS \\
\hline Baecke leisure & 0.005 & -0.009 & 0.02 & NS & -0.007 & -0.02 & 0.007 & NS & 0.01 & -0.02 & 0.04 & NS \\
\hline Sports (h/week) & 0.9 & 0.05 & 1.9 & NS & -0.4 & -1.0 & 0.3 & NS & -0.3 & -0.5 & -0.08 & $<0.01$ \\
\hline $\mathrm{VO}_{2 \max }(\mathrm{mL} / \mathrm{min} / \mathrm{kg} \mathrm{FFM})$ & 0.2 & 0.02 & 0.3 & $<0.05$ & -0.1 & -0.3 & 0.06 & NS & -0.4 & -0.7 & 0.01 & 0.05 \\
\hline
\end{tabular}

$B$, Unstandardized regression coefficient; $95 \% \mathrm{CI}, 95 \%$ confidence interval of $B ; \mathrm{PA}_{\mathrm{DL}}$, habitual physical activity in daily life in Megacounts per day; \%Low, $\%$ Moderate and \%High, proportion of time subjects were physically activity at a low, moderate and high intensity, respectively; $\mathrm{PA}_{\text {index }}$, total activity index measured with the Baecke questionnaire; Baecke Work, Sport and Leisure, scores on each section of the Baecke questionnaire; Sports, weekly time spent on sports in hours; $\mathrm{VO}_{2}$-max , maximal oxygen uptake expressed in $\mathrm{ml}_{2}$ per minute per kg fat-free mass; \%Type I, \%Type $\mathrm{II}_{\mathrm{A}}$ and \%Type $\mathrm{II}_{\mathrm{X}}$, proportion of type $\mathrm{I}_{\mathrm{I}} \mathrm{II}_{\mathrm{A}}$ and $\mathrm{II}_{\mathrm{X}}$ muscle fibers.

cannot explain the large inter-individual variation in $\mathrm{PA}_{\mathrm{DL}}$ that results from genetic variation. In concurrence with this finding, no association was found between the $\mathrm{PA}_{\text {index }}$ and Muscle $\mathrm{FTD}$. Moreover, no relationship was observed between \%Low, \%Moderate, and $\%$ High with Muscle $_{\mathrm{FTD}}$, indicating that Muscle $_{\text {FTD }}$ does not affect the proportion of time subjects spend in each of the three intensity categories.

Subjects spent 30 and $11 \mathrm{~min} /$ day on moderate and high-intensity physical activity, respectively. These values are close to those recently reported in other studies that used accelerometry in healthy, young adults (Yoshioka et al., 2005; Dinger \& Behrens, 2006). McClain et al. (2007) recruited regular runners and obtained a \%Moderate similar to that observed in the present study $(27 \mathrm{~min} /$ day $)$. \% High, on the other hand, was more pronounced in the subjects recruited by McClain et al. (48 $\mathrm{min} /$ day). This suggests that although highly physically active subjects were evidently recruited in the present study, the proportion of high-intensity physical activity was lower than observed previously for people actively engaged in endurance sports.

The association between $\mathrm{PA}_{\text {leisure }}$ and Muscle FTD $_{\text {FT }}$ found by others (Tikkanen et al., 1998; Hedman et al., 2002; Karjalainen et al., 2006) was not affirmed in the present study. This discrepancy may partly result from a difference in the health status of the subjects. Contrary to our population, which contained only healthy subjects, Hedman et al. (2002) recruited subjects from a cohort of 70-year-old men. When performing the analysis on healthy subjects only, no association between PA $_{\text {leisure }}$ and Muscle $_{\text {FTD }}$ remained. In the study of Tikkanen et al. (1998) and a recent follow-up study in the same population (Karjalainen et al., 2006) only healthy subjects were recruited. However, the method used in these studies to assess $\mathrm{PA}_{\text {leisure }}$ did not distinguish between physical activity during leisure-time and sports. As an association between the weekly time spent on sports and Muscle $_{\text {FTD }}$ was observed in the present study, we speculate that the relationship between $\mathrm{PA}_{\text {leisure }}$ and Muscle $_{\text {FTD }}$ found by Tikkanen et al. and Karjalainen et al. actually resulted from sports rather than leisure-time per se.

On average, subjects reported to spend $2 \mathrm{~h}$ /week on sports. A significant relationship was observed between the time weekly spent on sports and \% Type $\mathrm{II}_{\mathrm{X}}$. The power of this association was $0.84(\alpha=0.05$, one predictor, $\left.R^{2}=0.19, n=38\right)$. Furthermore, the weekly time spent on sports tended to correlate positively with \%Type I. Owing to the cross-sectional design of this study, no conclusions about causality can be drawn. However, previous studies showed that both endurance and strength training can induce a shift in Muscle $_{\mathrm{FTD}}$ from type $\mathrm{II}_{\mathrm{X}}$ to type $\mathrm{II}_{\mathrm{A}}$, i.e., toward a more oxidative phenotype (Andersen \& Henriksson, 1977; Ingjer, 1979; Howald et al., 1985; Simoneau et al., 1985; Sale et al., 1990; Coggan et al., 1992; Staron et al., 1994). For example, Staron et al. (1994) showed that in untrained subjects, \% Type $\mathrm{II}_{\mathrm{X}}$ decreased significantly already after four sessions of strength training within 2 weeks. This implies that even a small difference in training status may have resulted in the relationship found between the time spent on sports and \% Type $\mathrm{II}_{\mathrm{X}}$. The decreased \% Type $\mathrm{II}_{\mathrm{X}}$ is therefore considered an effect rather than a cause of an increased time spent on sports.

Contrary to transitions from type $\mathrm{II}_{\mathrm{X}}$ to type $\mathrm{II}_{\mathrm{A}}$, the majority of studies performed did not find an increased \% Type I following a period of either endurance or strength training (Gollnick et al., 
Fiber-type distribution and physical activity

1973; Saltin et al., 1976; Andersen \& Henriksson, 1977; Ingjer, 1979; Coggan et al., 1992; Staron et al., 1994). For example, \% Type I was not altered after 24 weeks of intensive endurance training in previously untrained women (Ingjer, 1979). Therefore, the increased time spent on sports may actually result from an increased \% Type I. In other words: subjects with a higher \%Type I may be more prone to engaging in sports. Since the time spent on sports was used as an exclusion criterion, its range was limited. This may explain why the association with $\%$ Type I did not reach significance.

In conclusion, Muscle FTD $_{\text {pD }}$ probably cannot explain why some people are more prone to engaging in physical activities than others. To generalize the findings, the measurements should be replicated.

\section{Perspectives}

The association between $\mathrm{PA}_{\mathrm{DL}}$ and Muscle $_{\mathrm{FTD}}$ was determined for the first time, using an objective and validated method to determine physical activity for a prolonged period of time. In spite of the association between physical fitness and Muscle $_{\mathrm{FTD}}$, no evidence was found for a relationship between $\mathrm{PA}_{\mathrm{DL}}$ and Muscle $_{\text {FTD. This indicates that physical fitness and }}$ physical activity are two non-synonymous entities that should not be used interchangeably. It also suggests that variables other than Muscle $_{\text {FTD }}$ probably determine why some people are more physically active than others. Future research is required to identify these variables.

Key words: accelerometers, myosin heavy chain isoforms, sports, exercise, heredity.

\section{Acknowledgements}

We thank Milou Beelen, Luc van Loon, and René Koopman for their skilful way of obtaining the muscle biopsies. We also thank Gert Schaart for his technical assistance and Loek Wouters for analyzing the deuterium samples.

\section{References}

Ainsworth BE, Haskell WL, Whitt MC, Irwin ML, Swartz AM, Strath SJ, O'Brien WL, Bassett DR Jr., Schmitz KH, Emplaincourt PO, Jacobs DR Jr., Leon AS. Compendium of physical activities: an update of activity codes and MET intensities. Med Sci Sports Exerc 2000: 32(9 Suppl.): S498-S504.

Andersen P, Henriksson J. Training induced changes in the subgroups of human type II skeletal muscle fibres. Acta Physiol Scand 1977: 99(1): 123-125.

Baecke JA, Burema J, Frijters JE. A short questionnaire for the measurement of habitual physical activity in epidemiological studies. Am J Clin Nutrit 1982: 36(5): 936-942.

Bell RD, MacDougall JD, Billeter R, Howald H. Muscle fiber types and morphometric analysis of skeletal msucle in six-year-old children. Med Sci Sports Exerc 1980: 12(1): 28-31.

Bergstrom J. Percutaneous needle biopsy of skeletal muscle in physiological and clinical research. Scand J Clin Lab Invest 1975: 35(7): 609-616.

Black AE, Coward WA, Cole TJ, Prentice AM. Human energy expenditure in affluent societies: an analysis of 574 doubly-labelled water measurements. Eur J Clin Nutrit 1996: 50(2): 72-92.

Coggan AR, Spina RJ, King DS, Rogers MA, Brown M, Nemeth PM, Holloszy JO. Skeletal muscle adaptations to endurance training in 60 - to 70 -yr-old men and women. J Appl Physiol 1992: 72(5): 1780-1786.

Dinger MK, Behrens TK. Accelerometerdetermined physical activity of freeliving college students. Med Sci Sports Exerc 2006: 38(4): 774-779.

Edstrom L, Nystrom B. Histochemical types and sizes of fibres in normal human muscles. A biopsy study. Acta Neurol Scand 1969: 45(3): 257-269.

Ekelund U, Aman J, Yngve A, Renman C, Westerterp K, Sjostrom M. Physical activity but not energy expenditure is reduced in obese adolescents: a casecontrol study. Am J Clin Nutrit 2002: 76(5): 935-941.

Esparza J, Fox C, Harper IT, Bennett $\mathrm{PH}$, Schulz LO, Valencia ME, Ravussin E. Daily energy expenditure in Mexican and USA Pima indians: low physical activity as a possible cause of obesity. Int J Obes Relat Metab Disord 2000: 24(1): 55-59.

Evertsen F, Medbo JI, Jebens E, Gjovaag TF. Effect of training on the activity of five muscle enzymes studied on elite cross-country skiers. Acta Physiol Scand 1999: 167(3): 247-257.

Gollnick PD, Armstrong RB, Saltin B, Saubert CWT, Sembrowich WL, Shepherd RE. Effect of training on enzyme activity and fiber composition of human skeletal muscle. J Appl Physiol 1973: 34(1): 107-111.

Gollnick PD, Matoba H. The muscle fiber composition of skeletal muscle as a predictor of athletic success. An overview. Am J Sports Med 1984: 12(3): 212-217.

Hedman A, Byberg L, Reneland R, Lithell HO. Muscle morphology, selfreported physical activity and insulin resistance syndrome. Acta Physiol Scand 2002: 175(4): 325-332.

Heitmann BL, Kaprio J, Harris JR, Rissanen A, Korkeila M, Koskenvuo M. Are genetic determinants of weight gain modified by leisure-time physical activity? A prospective study of Finnish twins. Am J Clin Nutrit 1997: 66(3): 672-678.

Howald H, Hoppeler H, Claassen H, Mathieu O, Straub R. Influences of endurance training on the ultrastructural composition of the different muscle fiber types in humans. Pflugers Arch 1985: 403(4): 369-376.

Ingjer F. Effects of endurance training on muscle fibre ATP-ase activity, capillary supply and mitochondrial content in man. J Physiol 1979: 294: 419-432.

Jaworowski A, Porter MM, Holmback AM, Downham D, Lexell J. Enzyme activities in the tibialis anterior muscle of young moderately active men and women: relationship with body composition, muscle cross-sectional area and fibre type composition. Acta Physiol Scand 2002: 176(3): 215-225.

Joosen AM, Gielen M, Vlietinck R, Westerterp KR. Genetic analysis of physical activity in twins. Am J Clin Nutrit 2005: 82(6): 1253-1259. 


\section{den Hoed et al.}

Karjalainen J, Tikkanen H, Hernelahti M, Kujala UM. Muscle fiber-type distribution predicts weight gain and unfavorable left ventricular geometry: a 19 year follow-up study. BMC Cardiovasc Disord 2006: 6(1): 2.

Komi PV, Viitasalo JH, Havu M, Thorstensson A, Sjodin B, Karlsson J. Skeletal muscle fibres and muscle enzyme activities in monozygous and dizygous twins of both sexes. Acta Physiol Scand 1977: 100(4)385-392.

Kriketos AD, Baur LA, O'Connor J, Carey D, King S, Caterson ID, Storlien LH. Muscle fibre type composition in infant and adult populations and relationships with obesity. Int $\mathbf{J}$ Obes Relat Metab Disord 1997: 21(9): 796-801.

Lortie G, Simoneau J-A, Boulay MR, Bouchard C. Muscle fiber type composition and enzyme activities in brothers and monozygotic twins. In: The 1984 Olympic scientific congress proceedings volume 4 :Sport and human genetics. Robert MM, Claude B. ed. Champaign, IL: Human Kinetics, 1986: 147-153.

McClain JJ, Sisson SB, Tudor-Locke C. Actigraph accelerometer interinstrument reliability during free-living in adults. Med Sci Sports Exerc 2007: 39(9): 1509-1514.

Philippaerts RM, Westerterp KR, Lefevre J. Doubly labelled water validation of three physical activity questionnaires. Int J Sports Med 1999: 20(5): 284-289.

Plasqui G, Joosen AM, Kester AD, Goris AH, Westerterp KR. Measuring free-living energy expenditure and physical activity with triaxial accelerometry. Obes Res 2005: 13(8): 1363-1369.

Ravussin E, Swinburn BA.

Pathophysiology of obesity. Lancet 1992: 340(8816): 404-408.

Sale DG, MacDougall JD, Jacobs I, Garner S. Interaction between concurrent strength and endurance training. J Appl Physiol 1990: 68(1) 260-270.

Saltin B, Nazar K, Costill DL, Stein E, Jansson E, Essen B, Gollnick D. The nature of the training response; peripheral and central adaptations of one-legged exercise. Acta Physiol Scand 1976: 96(3): 289-305.

Schoeller DA, Shay K, Kushner RF. How much physical activity is needed to minimize weight gain in previously obese women? Am J Clin Nutrit 1997: 66(3): 551-556.

Simoneau JA, Bouchard C. Genetic determinism of fiber type proportion in human skeletal muscle. Faseb J 1995: 9(11): 1091-1095.

Simoneau JA, Lortie G, Boulay MR, Marcotte M, Thibault MC, Bouchard C. Human skeletal muscle fiber type alteration with high-intensity intermittent training. Eur J Appl Physiol Occup Physiol 1985: 54(3): 250-253.

Siri WE. Body composition from fluid spaces and density: analysis of methods. 1961. Nutrition 1993: 9(5): 480-491; discussion 480, 492.

Staron RS, Hagerman FC, Hikida RS, Murray TF, Hostler DP, Crill MT, Ragg KE, Toma K. Fiber type composition of the vastus lateralis muscle of young men and women. J Histochem Cytochem 2000: 48(5): 623-629.
Staron RS, Karapondo DL, Kraemer WJ, Fry AC, Gordon SE, Falkel JE, Hagerman FC, Hikida RS. Skeletal muscle adaptations during early phase of heavy-resistance training in men and women. J Appl Physiol 1994: 76(3): 1247-1255.

Tikkanen HO, Hamalainen E, Sarna S, Adlercreutz $\mathrm{H}$, Harkonen M. Associations between skeletal muscle properties, physical fitness, physical activity and coronary heart disease risk factors in men. Atherosclerosis 1998: 137(2): 377-389.

Wardle J, Guthrie C, Sanderson S, Birch L, Plomin R. Food and activity preferences in children of lean and obese parents. Int J Obes Relat Metab Disord 2001: 25(7): 971-977.

Weinsier RL, Hunter GR, Heini AF, Goran MI, Sell SM. The etiology of obesity: relative contribution of metabolic factors, diet, and physical activity. Am J Med 1998: 105(2): 145-150.

Westerterp KR. Pattern and intensity of physical activity. Nature 2001: 410(6828): 539.

Westerterp KR, Wouters L, van Marken Lichtenbelt WD. The Maastricht protocol for the measurement of body composition and energy expenditure with labeled water. Obes Res 1995: 3(Suppl. 1): 49-57.

Yoshioka M, Ayabe M, Yahiro T, Higuchi H, Higaki Y, St-Amand J, Miyazaki H, Yoshitake Y, Shindo M, Tanaka H. Long-period accelerometer monitoring shows the role of physical activity in overweight and obesity. Int $\mathbf{J}$ Obes (Lond) 2005: 29(5): 502-508. 